\title{
Italians fail to overturn restrictive reproduction law
}

\author{
Fabio Turone Milan
}

Only one Italian in four voted in the referendum last Sunday and Monday to modify the country's highly restrictive law on assisted reproduction. This number fell far short of the quorum of more than $50 \%$ needed to change the law.

The referendum posed several questions about the law, which was approved last year by the centre right government (BMJ 2004;328:9). It asked whether respondents wanted to lift the ban on the use of donated eggs and sperm, embryo research and freezing, and the fertilisation of more than three eggs at a time. It also asked whether doctors should continue to be obliged to implant into the womb immediately all embryos created by in vitro fertilisation (without the possibility of preimplantation diagnosis) Finally, it asked about cancelling the section of the law that defended the rights of all involved parties, including the embryo.

Most of the scientific community sided with the referendum. Nobel laureates Rita Levi-Montalcini and Renato Dulbecco and the oncologist and former health minister Umberto Veronesi, among many others, appealed to voters to vote "yes." Biologist Angelo Vescovi and geneticist Bruno Dalla Piccola were among the most prominent scientists in favour of the law.

The public debate was heated and emotionally charged, especially after the Catholic church appealed to Italian citizens not to vote, saying that "life cannot be put to a vote." The move was intended to keep the turnout below the quorum (as in all previous referendums held since 1995), while convincing the citizens that the issues were too complicated to be understood and decided by a popular vote.
Political coalitions were torn apart, with centre left politicians backing the referendum and centre right politicians defending the law but with important exceptions. Gianfranco Fini, deputy prime minister and foreign affairs minister and president of the rightwing party Alleanza Nazionale, campaigned for the referendum. But Francesco Rutelli, the former

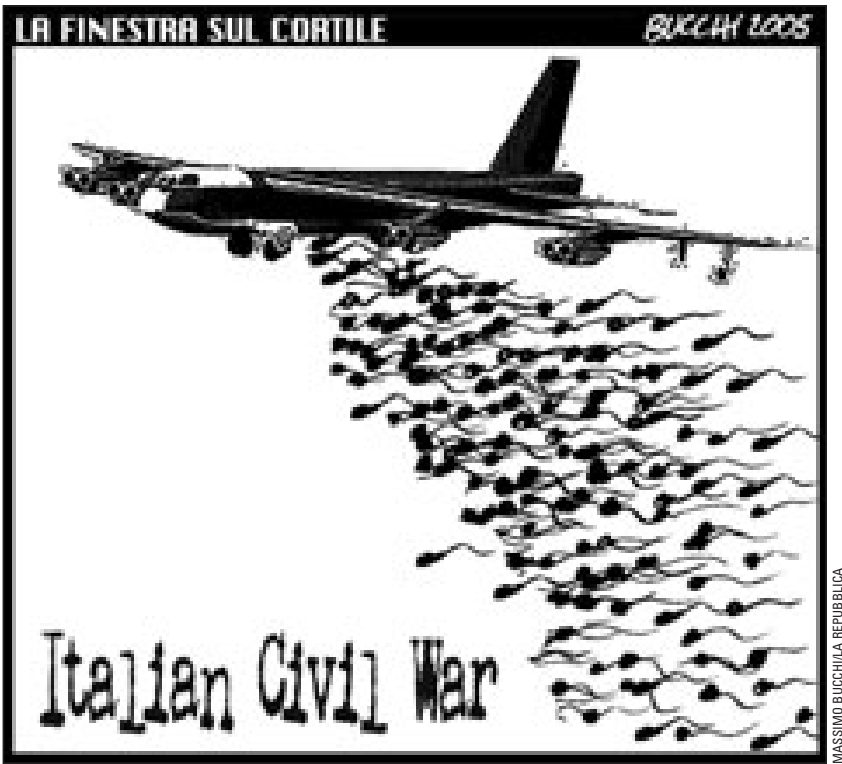

How the Italian newspaper La Repubblica saw the referendum

centre left prime minister, opted for abstention.

"The referendum was lost by a margin that I wouldn't have expected," commented Emma Bonino, former European Union commissioner and one of the proponents of the vote. "Today we have three victims: the secularism of the state, political authority, and the institution of the referendum."

Participation was $25.9 \%$. It was higher in the northern regions and in big cities, such as Rome and Milan, and lower in the south and the provinces. Some surveys indicated that

most of the voters had a high level of education. As for the votes expressed, the yes votes ranged from $78 \%$ (in favour of zygote donations) to around $90 \%$ (all other points).

After this victory of unexpected proportions for the "abstention party," the president of the Italian bishops, Cardinal Camillo Ruini expressed satisfaction, while insisting that the
BMJ VOLUME $330 \quad 18$ JUNE 2005 bmj.com the year after the new law came into effect the number of Italian couples going abroad for infertility treatments grew from 1315 to 3610 . The favourite destination is Spain $(26 \%$ of couples choose it because of low costs and liberal legislation) followed by Switzerland and Belgium.

The European Society of Human Reproduction and Embryology, a voluntary organisation representing 4500 international fertility experts worldwide, expressed dismay at the failure of voters to overturn the strict Italian fertility laws and warned that the Catholic church was now likely to step up its stand against biomedical research and fertility treatment.

"This is a sad day for infertile couples-and Italian infertile couples in particular," said the society's chairman, Arne Sunde. He warned that the Vatican's intervention sent a strong signal to infertile couples in Catholic countries everywhere.

"The Vatican has this time actively intervened in Italian politics by urging people not to vote. Infertile couples in other regions where the Catholic church has political influence must now anticipate that it will take a much stronger stand against biomedical research and treatment, including assisted reproduction," he said.

The society has consistently condemned as "deplorable" the controversial Italian legislation, which includes the banning of donor sperm, eggs, or surrogate mothers and restricts assisted fertilisation to stable heterosexual couples. In particular it has criticised the ban on embryo freezing and the ruling that doctors can create up to three embryos during each attempt at insemination, but must transfer all to the woman's uterus at the same time, thus risking multiple births with all the consequent risk to mothers and babies. 